\title{
De rol van accounting en accountingonderzoek in de economische crisis
}

Citation for published version (APA):

Vanstraelen, A. (2009). De rol van accounting en accountingonderzoek in de economische crisis. Maastricht University. https://doi.org/10.26481/spe.20090911av

Document status and date:

Published: 11/09/2009

DOI:

10.26481/spe.20090911av

Document Version:

Publisher's PDF, also known as Version of record

\section{Please check the document version of this publication:}

- A submitted manuscript is the version of the article upon submission and before peer-review. There can be important differences between the submitted version and the official published version of record.

People interested in the research are advised to contact the author for the final version of the publication, or visit the DOI to the publisher's website.

- The final author version and the galley proof are versions of the publication after peer review.

- The final published version features the final layout of the paper including the volume, issue and page numbers.

Link to publication

\footnotetext{
General rights rights.

- You may freely distribute the URL identifying the publication in the public portal. please follow below link for the End User Agreement:

www.umlib.nl/taverne-license

Take down policy

If you believe that this document breaches copyright please contact us at:

repository@maastrichtuniversity.nl

providing details and we will investigate your claim.
}

Copyright and moral rights for the publications made accessible in the public portal are retained by the authors and/or other copyright owners and it is a condition of accessing publications that users recognise and abide by the legal requirements associated with these

- Users may download and print one copy of any publication from the public portal for the purpose of private study or research.

- You may not further distribute the material or use it for any profit-making activity or commercial gain

If the publication is distributed under the terms of Article $25 \mathrm{fa}$ of the Dutch Copyright Act, indicated by the "Taverne" license above, 


\section{Maastricht University}

Prof. dr. Ann Vanstraelen

School of Business and Economics

De rol van accounting en accountingonderzoek in de economische crisis

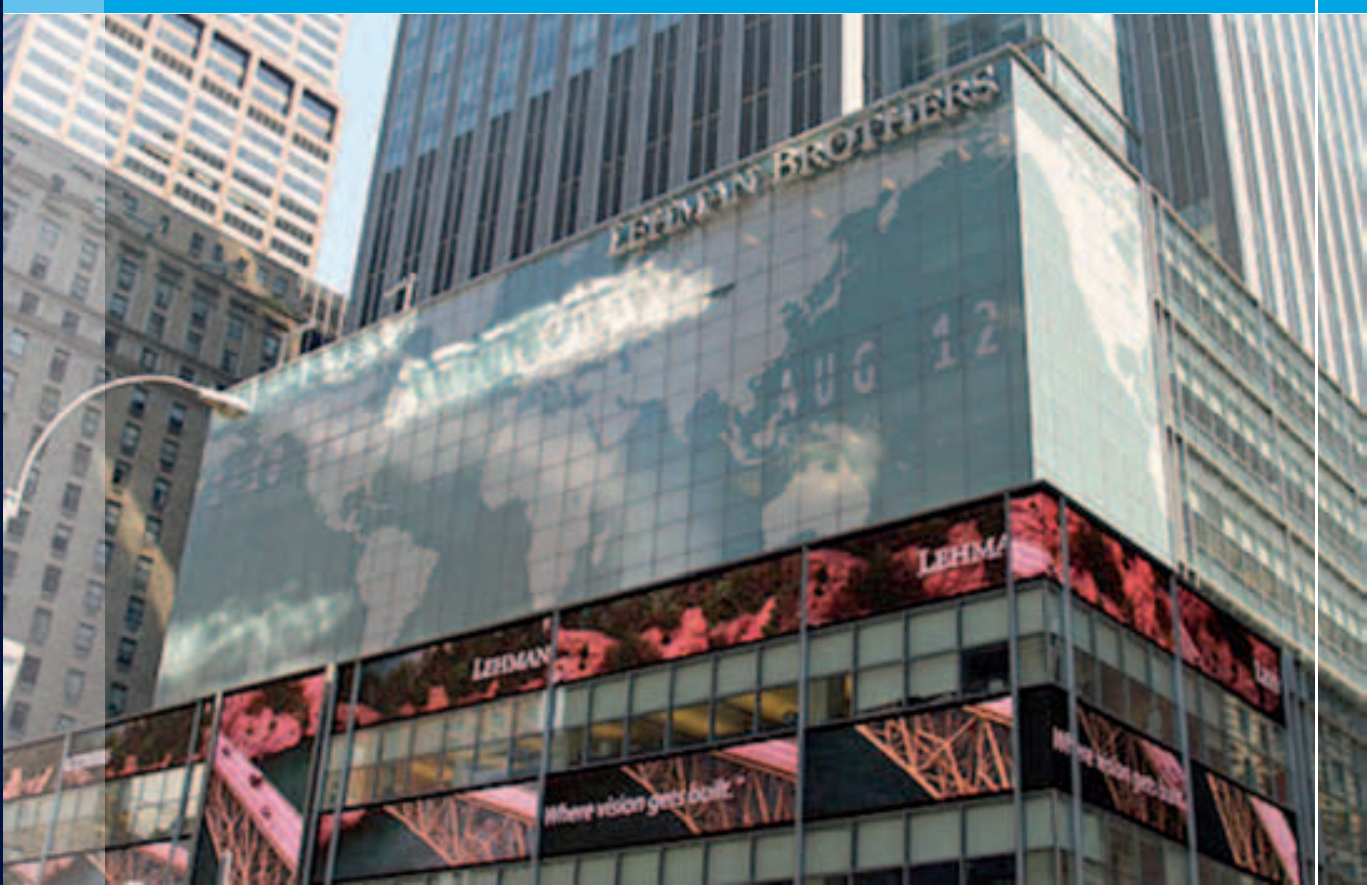


De rol van accounting

en accountingonderzoek

in de economische crisis 


\section{Colofon}

Design and print: Océ Business Services, Maastricht

ISBN: 978-90-5681-318-5

NUR: 780

Alle rechten voorbehouden. Niets uit deze uitgave mag worden verveelvoudigd, opgeslagen in een geautomatiseerd gegevensbestand of openbaar gemaakt worden, zonder voorafgaande schriftelijke toestemming van de auteur of uitgever. 


\section{De rol van accounting en accountingonderzoek in de economische crisis}

Rede

in verkorte vorm uitgesproken bij de aanvaarding van het ambt van hoogleraar accounting en assurance services, aan de Universiteit Maastricht

op vrijdag 11 september 2009

door

Prof. dr. A. Vanstraelen 
De rol van accounting en accountingonderzoek in de economische crisis 


\section{Inhoudsopgave}

1. Inleiding 7

2. Wat liep er fout en voor welke bijkomende gevaren 9 moeten we ons behoeden?

2.1 Oorzaken economische crisis 9

2.2 Rol van accounting in brede zin $\quad 10$

2.2.1 Accountingstandaarden 10

2.2.2 Politieke inmenging $\quad 14$

2.2.3 Accountants 18

2.3 Rol van accountingonderzoek 23

3. Enkele aanbevelingen 26

3.1 Regelgeving en toezicht 26

$\begin{array}{ll}3.2 & \text { Onderzoek } \\ 3.3 & 27\end{array}$

3.3 Financiële verslaggeving 28

4. Dankwoord 29

5. Referenties 31 
De rol van accounting en accountingonderzoek in de economische crisis 
Mijnheer de Rector Magnificus,

Zeer gewaardeerde toehoorders,

\section{Inleiding}

Als men mij vraagt: "Wat doe je beroepshalve?", antwoord ik: "Ik ben hoogleraar aan de universiteit". Met een betekenisvolle blik volgt dan de reactie: "Interessant. Welk vakgebied?", waarop ik antwoord: "Accounting". In plaats van een betekenisvolle blik volgt er dan meestal een bedenkelijke blik, en de vraag: "Is dat niet saai?". Deze vraag is ingegeven vanuit de gedachte dat in de huidige maatschappij alles spannend, hot en sexy moet zijn, en accounting blijkt dit niet te zijn. Welnu, accounting is dit tegenwoordig wel. Burton Malkiel, hoogleraar economie aan het prestigieuze Princeton University stelde onlangs: "De boekhouding van een bedrijf kan worden vergeleken met een bikini: wat ze toont is interessant, wat ze verbergt is essentieel."

Financiële rapportering heeft een maatschappelijke rol te vervullen. Het is de verantwoordelijkheid van het management om ervoor te zorgen dat financiële verslaggeving een betrouwbaar inzicht geeft in de financiële positie, prestaties en kasstromen van een onderneming. Aandeelhouders en andere belanghebbende partijen moeten daarop kunnen vertrouwen. Zij verwachten transparantie en inzicht in de risico's waaraan de onderneming is blootgesteld, en hoe deze worden beheerst. Precies op dit vlak is er iets fundamenteel fout gegaan, en met name in de financiële sector. De economische gevolgen hiervan zijn dermate groot dat we inmiddels in de zwaarste economische crisis zijn beland sinds de (19)30 jaren.

Het Chinese teken voor crisis bestaat uit twee karakters: enerzijds gevaar en anderzijds uitdaging. Een crisis heeft iets dreigends, maar je kan het ook positief ombuigen. Dit vormt de kern van mijn oratie. Vooreerst zal ik reflecteren op hoe we in deze gevaarlijke situatie zijn geraakt en voor welke bijkomende gevaren we ons moeten behoeden. Vervolgens zal ik een aantal aanbevelingen formuleren. Ik zal betogen dat de discussie zich niet moet concentreren op de ideologische as of er al dan niet meer regelgeving en toezicht moet zijn, maar wel rond de vraag wat is optimale regelgeving, en welke vorm van toezicht is efficiënt en effectief. Om deze vraag te beantwoorden, pleit ik voor meer interactie tussen onderzoekers enerzijds, en regelgevers en toezichthouders anderzijds. 
Verder zal ik betogen dat aanpassingen aan accountingstandaarden met de grootste zorg dienen te gebeuren, en we ons moeten behoeden voor boekhoudkundige kunstgrepen die het beeld van investeerders vertroebelen en tot inefficiënte economische besluitvorming leiden. 


\section{Wat liep er fout en voor welke bijkomende gevaren moeten we ons behoeden?}

\subsection{Oorzaken economische crisis}

Post-mortem analyses van de economische crisis zijn inmiddels legio en over haar oorzaken is al uitvoerig gedebatteerd. Het is welbekend dat de crisis haar oorsprong vindt in de Amerikaanse hypotheekmarkt voor vastgoed welke aanleiding heeft gegeven tot een kredietcrisis die is uitgegroeid tot een brede financiële crisis en uiteindelijk een omslag heeft gemaakt naar de reële globale economie. Zonder hier verder op in te gaan, wordt er in de media en rapporten van adviesgroepen (bv. rapport van 'de Larosière group' van de EU, 25 februari 2009, en het 'Turner Review' rapport, maart 2009) met de vinger gewezen naar: de steeds toenemende schuldfinanciering (zie grafiek 1); bankiers die zich roekeloos hebben gedragen; de complexiteit van het bankieren en de producten zoals de CDOs ('collateralized debt obligations') die niet goed begrepen werden, soms ook niet door de top van de bank, met fundamentele fouten in risico-inschatting tot gevolg; een gebrek aan ethiek; het excessief beloningsbeleid en perverse beloningsprikkels; toezichthouders die toelieten dat banken veel te dun gefinancierd waren, wat hen erg kwetsbaar maakt zelfs bij een kleine procentuele waardedaling van activa; kredietratingbureaus die door belangenverstrengeling bijdroegen aan de zeepbel; economen, die op enkele uitzonderingen na, deze crisis niet hebben zien aankomen, en onvoldoende waarschuwingssignalen hebben afgegeven; en beleggers die zich hebben laten wijsmaken dat de bomen tot in de hemel groeien en men geen genoegen moet nemen met een normaal rendement.

Naast deze factoren wordt er in de media ook verwezen naar de accountingstandaarden die door bedrijven en banken moeten worden toegepast, en naar de accountants die goedkeurende verklaringen hebben afgeleverd aan banken die zich blootstelden aan buitengewoon grote risico's. Daar ik benoemd werd tot hoogleraar accounting en assurance services, is het gepast dat ik hier nu uitvoeriger op inga en dit brengt mij bij de rol van accounting in brede zin. 
Grafiek 1: Uitstaand consumentenkrediet in de VS (in \$ miljard)

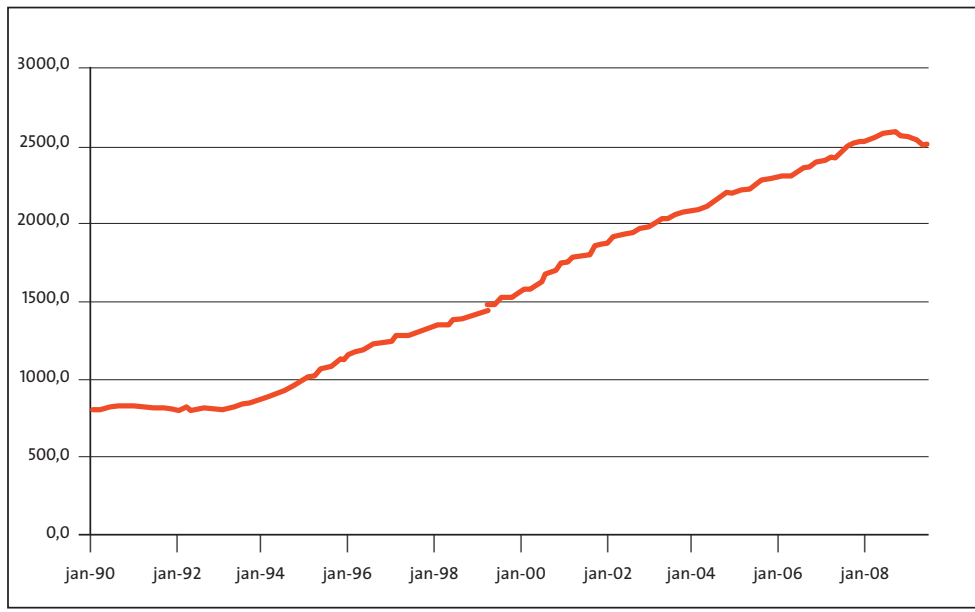

Bron: Wikipedia

\subsection{Rol van accounting in brede zin}

\subsubsection{Accountingstandaarden}

Sinds het uitbreken van de crisis hebben de boekhoudregels of accountingstandaarden die toegepast moeten worden meer tegenstanders dan voorvechters gekend in de financiële wereld, en worden ze door diverse CEOs van banken aangeduid als oorzaak voor de neergang van hun beurskoersen. In het bijzonder is er kritiek op de toepassing van het zogenaamde "fair value accounting" (FVA). Voor de minder ingewijden onder $u$, FVA houdt in dat activa en verplichtingen worden gewaardeerd tegen fair value wat neerkomt op de actuele of marktconforme waarde. Formeel wordt fair value onder de Internationale Financiële Rapporteringsstandaarden (IFRS) gedefinieerd als het bedrag waarvoor een actief kan worden verhandeld of een verplichting kan worden afgewikkeld tussen terzake goed geïnformeerde, tot een transactie bereid zijnde partijen, die onafhankelijk zijn (IAS 32). In tegenstelling tot het traditionele principe van waardering tegen historische kostprijs, waarbij de klacht was dat het een beperkt nut had en weining relevante informatie oplevert voor het nemen van beslissingen, is het doel van FVA om een nauwere band te creëren tussen de activa, verplichtingen en resultaten van een onderneming, en de heersende economische omstandigheden. Inzicht in de economische waarde impliceert ook dat er meer volatiliteit is in 
de balans en winst- en verliesrekening bij veranderingen in de markt. Wanneer het economisch goed gaat, wordt het resultaat en het eigen vermogen aangedikt, maar wanneer het tij keert, moeten de producten waarvoor er minder belangstelling is, afgewaardeerd worden. Van de massale afboekingen, voornamelijk door de banken, zijn we in de afgelopen tijd allen getuige geweest. Vandaar de roep van de financiële wereld om de accountingstandaarden aan te passen. De centrale vraag die zich bijgevolg stelt is: Heeft FVA een rol gespeeld bij de financiële crisis en moeten de verslaggevingsregels worden aangepast? Deze vraag houdt ook regelgevers, toezichthouders en politici erg bezig.

Naar mijn oordeel is FVA niet verantwoordelijk voor de crisis. Deze mening wordt ook gedeeld door andere academici zoals Christian Leuz van de Universiteit van Chicago, adviesgroepen zoals de 'Financial Crisis Advisory Group', en vertegenwoordigers van accountantskantoren ('Policy and Regulatory Group'). De kern van de financiële crisis is te zoeken in de overdreven hoge graad van schuldfinanciering in de globale economie, het nemen van te hoge risico's, en de onderkapitalisatie van de banksector. Banken met een schuldgraad van 20 tot meer dan 30 keer het eigen vermogen waren helemaal niet ongebruikelijk (zie grafiek 2). Dit neemt niet weg dat FVA economische effecten kan hebben, of ze minimaal zichtbaar maakt. Zo komt toepassing van FVA extra hard aan wanneer kapitaalbuffers te dun zijn om verliezen op te vangen.

Grafiek 2: Toename leverage ratio investeringsbanken 2003-2007

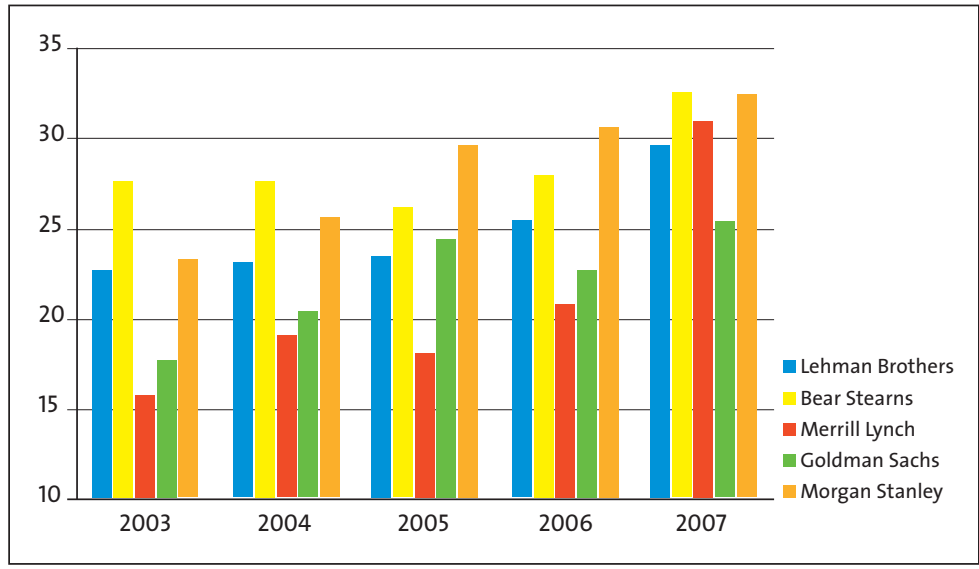

Bron: Data uit jaarverslagen (SEC Form 10K) 
Er wordt door sommigen beweerd dat FVA de ernst van de crisis heeft versterkt. Ook hier ben ik het niet mee eens, omdat FVA in haar zuivere vorm niet is voorzien in de geldende accountingstandaarden, noch in de internationale standaarden (IFRS), noch in de Amerikaanse standaarden (US GAAP). Zo zijn bv. afwijkingen van fair value mogelijk bij inactieve markten en mogen marktprijzen van gedwongen verkopen niet gebruikt worden precies als bescherming tegen een negatieve spiraal. De omvang van de crisis is wel sneller zichtbaar geworden door toepassing van FVA, maar vroeg of laat waren verliezen toch boven gekomen. Dit neemt niet weg dat marktprijzen soms kunnen afwijken van hun fundamentele waarde, en dat de markt niet op elk moment efficient is in de verwerking van publiek beschikbare informatie, maar dit geldt zowel in positieve als negatieve zin. Enkel in negatieve zin wordt de fair value als 'unfair' ervaren, maar hierbij mag niet vergeten worden dat de balans een momentopname is. Als je nu iets wil verkopen en er is geen markt voor, dan kan het niet, ook al is het redelijk te verwachten dat je het over enkele jaren wel opnieuw kan verkopen tegen een aanvaardbare prijs. Ook valt er inderdaad iets voor te zeggen dat FVA in haar zuivere vorm een besmettingseffect kan veroorzaken en een crisis ernstiger kan maken (zie Allen \& Carletti, 2008; Plantin, Sapra \& Shin, 2008). Toch lijkt het echter onwaarschijnlijk dat toepassing van FVA heeft geleid tot een algemene onderwaardering van activa. De niet-zuivere toepassing van FVA zoals voorzien in de geldende accountingstandaarden houdt ook een gemengd waarderingsmodel in ('mixed attribute model') wat betekent dat heel wat activa en verplichtingen, - ook financiële - , nog steeds gewaardeerd worden aan historische kostprijs waarin potentiële verliezen schuilen. De resultaten van stresstesten op banken lijken dit vermoeden te bevestigen.

Dit betekent niet dat toepassing van FVA, ook in haar vorm zoals voorzien door de huidige accountingstandaarden, zonder problemen is. De crisis heeft dit zonder twijfel duidelijk gemaakt, en een herziening van de accountingstandaarden is op bepaalde punten dan ook wenselijk (zie o.a. rapport van de 'Financial Crisis Advisory Group', 28 juli 2009). Zo stelt er zich ondermeer het probleem dat marktwaarden soms lastig te bepalen zijn, en er geen duidelijke fair value is wanneer een markt voor een product is opgedroogd en er geen liquiditeit meer is. Hierbij dient opgemerkt te worden dat accountingregels slechts relevant zijn omdat we in een imperfecte wereld leven met fricties en informatie asymmetrie. In geval van perfecte markten is rapporteren 
volgens marktwaarde optimaal maar tegelijkertijd ook overbodig (Laux \& Leuz, 2009). In geval van informatieasymmetrie hebben managers immers een informatievoordeel, en kijken 'standardsetters' aan tegen de klassieke afweging tussen relevantie en betrouwbaarheid. Model gebaseerde fair values kunnen in bepaalde omstandigheden relevanter zijn, maar marktprijzen zijn makkelijker te verifiëren en moeilijker te manipuleren. Dit is nu eenmaal de prijs die je betaalt voor informatie asymmetrie. Beleggers zouden zich overigens ook bewuster moeten zijn van de informatieachterstand die ze hebben (Suijs, 2008). Verder vragen de bestaande FVA standaarden, bij afwijking van de marktprijs, heel wat 'judgment' of beoordelingen van het management. Het is niet ondenkbaar dat deze beoordelingen door het management op een andere manier gebeuren in landen waar zij blootgesteld zijn aan hogere aansprakelijkheidsrisico's (Laux \& Leuz, 2009).

Andere problemen zijn dat verliezen m.b.t. ondermeer leningen, gestructureerde kredietproducten en andere financiële instrumenten te laat worden opgenomen. Ook laten de accountingstandaarden zeker in de VS nog teveel buiten-balans financiële structuren toe. Daarnaast zijn sommige accountingstandaarden veel te complex. De Autoriteit Financiële Markten (AFM), stelde in dit verband terecht dat net zoals de nieuwe eis dat bankiers geen producten mogen verkopen die ze niet begrijpen, er een vergelijkbare eis zou moeten zijn voor IFRS: zij moet kunnen worden uitgelegd door de gemiddelde CFO en accountant (uit lezing Hans Hoogervorst 30 oktober 2008). De internationale accountingstandaard m.b.t. opname en waardering van financiële instrumenten, IAS 39, is hier een goed voorbeeld van. Als anekdote geef ik u mee dat ik co-auteur ben van een boek rond IFRS en we het schrijven van het hoofdstuk rond financiële instrumenten bijna per lot moesten toewijzen omdat geen van de vijf auteurs hier zin in had.

Een aanpassing van sommige accountingstandaarden is dus wenselijk en de leidraad hierbij moet zijn dat de aanpassingen de transparantie bevorderen en de complexiteit verminderen. De 'Financial Crisis Advisory Group' is stellig in haar rapport van juli 2009 dat alle wijzigingen in financiële verslaggeving die de transparantie reduceren en de impact van de crisis verduisteren, het vertrouwen van marktparticipanten enkel maar verder zal verminderen, de crisis zal verlengen, en de basis legt voor nieuwe problemen in de toekomst. Inmiddels heeft de International Accounting Standards Board (IASB) deze zomer voorstellen (beschikbaar 
op www.iasb.org) gedaan om haar standaarden aan te passen. Dit brengt mij bij het volgende punt rond politieke inmenging.

\subsubsection{Politieke inmenging}

De aanpassingen die de IASB voorstelt zijn er voornamelijk gekomen onder politieke druk. In een interview in een financiële krant verdedigde Sir David Tweedie, voorzitter van de IASB, in februari 2009 nog de internationale accountingstandaarden (De Tijd, 12 februari 2009), maar is uiteindelijk toch bezweken onder de druk. De krantenkop "Boekhouders moeten plooien voor de politiek" in diezelfde financiële krant in juni 2009 liegt er niet om (De Tijd, 23 juni 2009). De belangen van de politiek zijn dan ook niet gering door de toegestane staatsgaranties aan diverse banken of zelfs nationalisaties waardoor ministers van financiën zichzelf als bankier beginnen op te stellen: als de balans er al slecht uitziet, is het laatste wat je wil dat je nog meer verliezen moet opnemen door accountingregels. Ook de G20, de belangrijkste 19 industrie- en groeilanden en de EU, vroeg in april 2009 om een herziening van IFRS. In het bijzonder werd de reeds genoemde IAS 39 geviseerd, welke banken verplicht grote delen van hun portefeuille elk kwartaal aan marktwaarde ('mark-to-market') aan te passen, met de gekende afwaarderingen tot gevolg en de noodzaak om extra kapitaal op te halen precies op een moment wanneer krediet schaars is. In 2008 werd er door de Europese banken voor 320 miljard euro aan waardeverminderingen geboekt, in het eerste kwartaal van 2009 kwam hier nog eens 40 miljard euro bij.

Een eerste versoepeling kwam er al in 2008, waarbij de mogelijkheid werd geboden om beleggingsproducten periodiek volgens een ander regime te waarderen wanneer de markt opdroogt. In maart 2009 kwamen er nieuwe aanbevelingen over hoe banken hun activa moeten uitboeken, om deze meer in lijn te brengen met US GAAP, en in juni, juli en augustus 2009 deed de IASB voorstellen rond financiële instrumenten met ondermeer nieuwe regels over hoe fair value het best wordt gewaardeerd, en over het aanleggen van reserves. Kort samengevat, komen de voorstellen neer op het verminderen van de complexiteit van de accountingstandaarden rond financiële instrumenten ondermeer door het aantal categorieën voor financiële instrumenten tot twee te reduceren, waarbij de ene categorie wordt gewaardeerd aan geamortiseerde kostprijs en de andere categorie aan fair value; het aanbieden van een leidraad voor hoe banken fair value moeten toepassen in geval de markt opdroogt; het toelaten van meer 
flexibiliteit voor het aanleggen van reserves; en het toelaten dat bepaalde financiële bezittingen en schulden niet langer tegen marktwaarde in de boeken moeten worden opgenomen. Dit laatste zou betekenen dat er een halt wordt toegeroepen aan de enorme afboekingen die op bepaalde bezittingen moeten worden doorgevoerd, wat de balans van de banken zou versterken en de leencapaciteit bevorderen (Bouwens, 27 juni 2009). Dit is precies wat de overheid graag wil. Of dit ook zo zal zijn, is overigens nog de vraag en zal mede afhangen van de aard van de financiële instrumenten in de portefeuille van banken. Dit neemt niet weg dat de overheid zich op een gevaarlijk pad begeeft, wanneer zij om een versoepeling van verslaggevingsstandaarden vraagt, en zich moet realiseren dat hierin enkele belangrijke gevaren sluipen.

Vooreerst zijn beleggers niet dom. Het niet boeken van verliezen wil niet zeggen dat ze er niet zijn. Je bedriegt dan ook beleggers door iets in de balans op te nemen aan 100 euro terwijl het maar 60 euro waard is. Ten tweede leidt het tot inefficiënte economische besluitvorming. Als iets 60 euro waard is terwijl het aan 100 euro in de balans staat, zal je niet bereid zijn te verkopen aan 70 euro omdat dit je balanspositie verslechtert. Een systeem van stelselmatig overwaarderen, ondermijnt dus het herstel van vertrouwen in de markt en is economisch contra-productief, zoals ook de ervaring bij de Japanse banken leert (zie o.a. Sinn, De Tijd, 2 juli 2009; en lezing Hoogervorst, 24 juni 2009). Wetenschappelijke studies (Peek \& Rosengren, 2005; Caballero, Hoshi \& Kashyap, 2008) hebben aangetoond dat een belangrijke verklaring voor de economische malaise in Japan die begin jaren (19)9o begon en meer dan tien jaar duurde, een fundamentele misallocatie van krediet was. Japanse banken hadden een incentive om leningen toe te staan aan zwak presterende of zelfs insolvabele ondernemingen, - zombies genoemd -, en dit om de realisatie van verliezen op hun balans te vermijden. M.a.w. er werden nieuwe leningen toegestaan opdat bestaande leningen niet zouden moeten worden afgeboekt. Het verlenen van leningen aan deze zogenaamde zombies resulteerde in een vermindering van de productiviteit en de winsten van de gezonde ondernemingen en ontmoedigde investeringen en toetreding tot de markt. Toezichthouders en regelgevers hebben deze praktijken gedoogd; op korte termijn had de overheid hier ook belang bij omdat faillissementen en bijkomende staatsinterventies hierdoor vermeden konden worden. 
Kortom, het negeren van marktprijzen of actuele informatie om een solider banksysteem te creëren, lijkt een illusie (Laux \& Leuz, 2009). Ook de markt onthouden van de resultaten van de stresstesten op de banken, zoals ondermeer de Britse toezichthouder recent weigerde te doen (De Standaard, 23-24 mei 2009), is niet wenselijk. De aangevoerde reden is dat dit onzekerheid op de financiële markten verder zou vergroten, wat de overheid opnieuw kan verplichten in te grijpen. Zelf denk ik dat het gebrek aan transparantie juist tot meer onzekerheid op de financiële markten leidt. Dit neemt niet weg dat het spanningsveld tussen transparantie en financiële stabiliteit erkend moet worden. Beurstoezichthouders pleiten voor transparantie, en vinden dat verliezen pas genomen moeten worden wanneer betalingsproblemen zich werkelijk voordoen (het zogenaamde 'incurred loss model'). Prudentiële regelgevers daarentegen, zijn bezorgd over de financiële stabiliteit en pleiten daarom voor het aanleggen van reserves in goede tijden om deze te gebruiken in slechte tijden (het zogenaamde 'expected loss model'). Dit noemen we in accounting 'income smoothing' of winstegalisatie, wat niet strookt met kwaliteitsvolle financiële verslaggeving. Een oplossing zou kunnen zijn dat de prudentiële regelgever reserves oplegt, nadat de winst is bepaald en gerapporteerd volgens de accountingstandaarden. Het is hierbij belangrijk dat de effecten van afwijkingen tussen accounting en prudentiële regelgeving gerapporteerd worden zonder de transparantie en integriteit van financiële rapportering te verminderen (zie rapport 'Financial Crisis Advisory Group', 28 juli 2009).

Hoewel, zoals gezegd, het totale effect van de nieuwe voorstellen van de IASB op de resultaten voorlopig onduidelijk lijkt en er ook discussie rond is, komt het er toch op neer dat bepaalde activa die nu nog aan marktwaarde in de boeken staan, plots veel meer waard zouden kunnen worden. Een boekhoudkundige kunstgreep dus, maar of investeerders hier genoegen mee nemen, valt te betwijfelen. Gemiddeld genomen zijn investeerders immers enkel bereid een hogere prijs te betalen voor een aandeel wanneer ze een duidelijk inzicht hebben in de risico's en de werkelijke economische waarde (zie o.a. lezing Hoogervorst, 30 oktober 2008). Hierbij aansluitend is het interessant op te merken dat niet alle banken zich even risicovol hebben opgesteld met het beleggen in complexe gestructureerde producten. Deze banken liepen weliswaar de winsten mis in de hausse-periode, maar moeten nu geen massale afboekingen doen en hebben geen nood aan staatssteun. De anderen bleven dansen zolang de muziek speelde, en zijn nu diegene die het 
hardst roepen om de regels te versoepelen. Centrale banken hebben bovendien instrumenten ter beschikking om eisen te stellen rond de hoogte van het eigen vermogen van banken, los van het gerapporteerde vermogen onder IFRS. In sommige landen hebben de centrale banken dit ook gedaan, en zo is er bv. in Canada geen enkele dollar besteed aan 'bailouts' van banken (i.e. redding van banken in financiële problemen).

Globaal genomen zijn de nieuwe voorstellen van de IASB goed in die mate dat het de complexiteit van de accountingstandaarden rond financiële instrumenten vermindert, en een leidraad aanbiedt voor toepassing van FVA wanneer de markt opdroogt, maar bepaalde aspecten van het voorstel dreigen het beeld van investeerders te vertroebelen. Precies op dit laatste punt kan men zich moeilijk van de indruk ontdoen dat de politieke inmenging zich hier heeft laten leiden door eigenbelangen. In een overzichtsartikel rond de geschiedenis van de Amerikaanse accountingstandaarden (US GAAP) toont Steve Zeff (2005) dat ondernemingen en zelfs overheidsdepartementen lobbyen en druk uitoefenen bij 'standardsetters' om geen standaarden goed te keuren die hun bedrijfsplannen en strategieën belemmeren. Financiële accountingstandaarden hebben, aldus Zeff, immers een impact op de economie in het algemeen en op de verdeling van inkomen, welvaart en risico. Voorlopig is er echter nog maar weinig wetenschappelijk werk (met enkele noemenswaardige uitzonderingen zoals Watts \& Zimmerman, 1978; Ramanna, 2008) verricht naar het lobbying proces door verschillende belanghebbende partijen waaronder de overheid, en de uitkomsten hiervan. Inzicht hierin zou in belangrijke mate kunnen bijdragen aan onze kennis rond deeconomische gevolgen vanaccountingstandaarden (Skinner, 2008). Terzijde opgemerkt, één van de eerste uitvoerende opdrachten van president Obama was het aan banden leggen van lobbyisten uit het bedrijfsleven omwille van hun te grote invloed op de overheid.

Het leidt dan ook geen twijfel dat het belangrijk is dat 'standardsetters' in alle onafhankelijkheid kunnen werken, maar wel met politieke verantwoording en onder toezicht in het algemeen belang. Dit wordt ook onderstreept in rapporten van adviesgroepen zoals van de 'Financial Crisis Advisory Group' (28 juli 2009) en het rapport van 'de Larosière group' van de EU (25 februari 2009). Terzijde opgemerkt, is één van de redenen van de complexiteit van de huidige regelgeving rond financiële instrumenten precies veroorzaakt door inmenging van verschillende belanghebbende partijen die zich hebben verzet tegen bepaalde 
bepalingen en een aanpassing eisten. Waar de politiek zich zeker voor moet behoeden, is het toelaten van afwijkingen van de internationale accountingstandaarden (IFRS) op landenniveau. Op die manier schiet IFRS haar doel van een uniforme set van standaarden voorbij en zou terug naar af betekenen voor de Europese en internationale kapitaalmarkten.

Het is echter niet allemaal slecht nieuws. De overheden in diverse landen en de EU hebben ook al verschillende goede maatregelen genomen, zoals het opleggen van hogere kapitaalbuffers voor banken, bijkomende verplichtingen tot informatieverschaffing, meer bevoegdheden voor toezichthoudende autoriteiten en een beheerst beloningsbeleid. Ter afronding van dit punt rond politieke inmenging beweerde president Nixon dat we soms allemaal Keynesianen zijn, maar alleen als het slecht gaat. Keynes schreef ooit: "Een kapitalist die geld investeert, gedraagt zich eerder als een gelovige dan als een rationele homo economicus. Als boeren zich zouden gedragen als aandeelhouders, zouden ze 's ochtends als het regent hun boerderij van de hand doen, om deze 's middags wanneer de zon schijnt weer terug te kopen. Keynes was zich dus goed bewust van irrationeel gedrag en potentiële crises. Maar ook Keynes dacht dat je met een verstandige politiek het systeem voor zijn kwalen kan behoeden" (Haegens, 21 januari 2009).

\subsubsection{Accountants}

Bij de financiële schandalen aan het begin van dit decennium (zoals Enron, Worldcom, Ahold, Parmalat) werd de accountant heel zwaar onder vuur genomen in de publieke opinie en was er sprake van een algemene vertrouwenscrisis in het accountantsberoep. Het omvallen van één van de vijf grootste spelers in de markt van accountantskantoren, Arthur Andersen, was schokkend en illustreert het belang van vertrouwen in de accountant. Vertrouwen is immers één van de hoekstenen opdat een audit waarde heeft (Kinney, 1999). Markten steunen op dit principe van vertrouwen, maar helaas soms ten onrechte...

In de huidige crisis zijn het aantal kritische geluiden aan het adres van de accountant relatief beperkter. Dit neemt niet weg dat er momenteel claims lopen tegen accountants zoals ondermeer tegen de accountants van fondsen die belegden bij Madoff, wiens ponzifraude $u$ wellicht allen bekend is, en er zeer scherpe reacties te lezen zijn in de media zoals: "De kredietcrisis heeft bewezen dat de externe accountantscontrole 
zinloos is" (Lakeman, 2009, www.accountingweb.nl), of "Accountants hebben niet in het openbaar gewaarschuwd voor de ramp die zich onder hun ogen voltrok" (Bouwens, 26 november 2008). Accountants hebben als poortwachter de crisis inderdaad niet zien aankomen, en sommige accountants geven dit ook toe (bv. Jules Muis in programma Buitenhof 30 november 2008). Het is inderdaad moeilijk uit te leggen aan het publiek dat banken de zegen krijgen van de accountant door jarenlang goedkeurende verklaringen af te geven terwijl de banken aan enorme risico's waren blootgesteld die niet of onvoldoende gedekt waren. Het voortbestaan van bepaalde banken was dus ernstig in gevaar en toch heeft de accountant hier niet voor gewaarschuwd. Om één voorbeeld te noemen, de grote Amerikaanse effectenbank Lehman Brothers kreeg een goedkeurende verklaring op 28 januari 2008 en op 10 juli 2008 werden er ook geen opmerkingen geformuleerd over de kwartaalcijfers, daar waar de bank zich begin augustus in ernstige financiële moeilijkheden bevond en op 14 september 2008 staking van betaling ('Chapter 11') aanvroeg. Als de overheid niet was ingesprongen, waren nog meer grote banken omgevallen. De perceptie dat er iets fout liep, wordt versterkt wanneer de ontvangen inkomsten voor en buiten de audit in beschouwing worden genomen: bij Lehman Brothers ging het om een bedrag van 110 miljoen dollar in de laatste vier jaar waarvan 14 miljoen dollar voor adviesverlening (Sikka, 18 september 2008, guardian. co.uk). Het Brits parlement (UK House of Commons Treasury Committee 2008) heeft overigens in de nasleep van de nationalisatie van Northern Rock, - de grote Britse hypotheekbank - , haar bezorgdheid geuit over het verlenen van advies aan auditklanten, wat bij Northern Rock 0.7 miljoen pond bedroeg t.o.v. een auditfee van 1.3 miljoen pond (Sikka, 2009). Dit doet de reeds lang bestaande discussie rond adviesverlening door accountants opnieuw herleven.

Vanuit economisch perspectief is het belangrijk te realiseren dat als een accountant handelt als een rationeel economisch agent, dit betekent dat hij bij zijn beslissingen een economische trade-off maakt tussen enerzijds de kans op reputatieverlies door aansprakelijkheidsclaims bij het afleveren van een onterechte goedkeurende verklaring, en anderzijds de kans op verlies van de klant door een andere dan een standaard goedkeurende verklaring af te geven. Terzijde opgemerkt, de verliezen die accountantskantoren effectief lijden door schadeclaims zijn relatief beperkt t.o.v. de inkomsten: het gaat om miljoenen tov. miljarden euro's. Door accountantskantoren wordt wel eens het 
omgekeerde beweerd: zij voeren de draconische miljardenclaims aan t.o.v. de relatief bescheiden inkomsten van de partnerships. Er dient echter een onderscheid gemaakt te worden tussen de initiële vordering ('claim') en de daadwerkelijke schikking ('settlement'), wat een ander beeld oplevert. In sommige landen wordt het aansprakelijkheidsrisico overigens beperkt. In België bv. is dit beperkt tot 12 miljoen euro. Ik weet niet of $u$ het balanstotaal van Fortis nog kent in betere tijden, maar dit is daar een peulschil van. Wetenschappelijk onderzoek heeft aangetoond dat een lager risico op aansprakelijkheid leidt tot een lagere auditkwaliteit (zie o.a. Francis \& Wang, 2008). Ook toonde onderzoek aan dat, na controle voor andere factoren, een verlichting van aansprakelijkheid van accountants in de VS midden jaren negentig resulteerde in minder meldingen van continuïteitsproblemen in de accountantsverklaring (Geiger \& Raghunandan, 2001). Een voormalig senior Vice-President van de Wereldbank stelde in dit verband: "In 1995, [US] Congress... provided substantial [liability] protection for the auditors. But we may have gone too far: insulated from suits, the accountants are now willing to take more 'gambles"' (Stiglitz, 2003, p.136). Verder weten we uit wetenschappelijk onderzoek, waaronder eigen werk, dat verschillen en wijzigingen in regels een effect hebben op het gedrag van accountants (zie o.a. Maijoor \& Vanstraelen, 2006; Carcello, Vanstraelen \& Willenborg, 2009).

Ingewijden in het vak weten dat de jaarrekening die de accountant controleert een getrouw beeld moet geven van de situatie zoals die zich momenteel voordoet. Maar situaties kunnen heel snel wijzigen, waar we overigens allen getuige van zijn geweest, en de vraag is dan: Mag je de accountant aanrekenen dat hij jaarcijfers over een voorgaande periode heeft goedgekeurd? Het antwoord is wellicht neen, en het lijkt erop dat de accountants van banken technisch voldeden aan alle geldende voorschriften en regels. Zo zouden accountants meermaals intern hebben gewaarschuwd voor risico's in de financiële sector (zie o.a. Helderman, 8 november 2008). Bovendien is de continuiteit van banken primair de verantwoordelijkheid van de centrale banken. Aan haar regels was voldaan; of het optimale regels waren, is een ander verhaal. $\mathrm{Er}$ mag ook niet vergeten worden dat de waarde van complexe financiële instrumenten afhangt van onzekere toekomstige gebeurtenissen en kan variëren van nul tot enkele miljoenen euro's (Sikka, 2009). In dit verband wordt in het rapport van de 'Financial Crisis Advisory Group'van juli 2009 gesteld dat gebruikers van de jaarrekening ook de beperkingen 
van financiële rapportering moeten kennen, en dat de kwaliteit van financiële rapportering ook bepaald wordt door de betrouwbaarheid van de onderliggende data die gebruikt worden voor de waardering van activa en verplichtingen, welke afhankelijk is van goed functionerende markten met een degelijke infrastructuur om tijdige, betrouwbare en relevante data aan te leveren.

Dat accountants niet echt iets te verwijten valt, is ook de conclusie van gekende academici in het vakgebied zoals Mike Power van de London School of Economics (memorandum, januari 2009) en van bepaalde overheden zoals het Brits parlement (House of Commons Treasury Committee, 2009). De Nederlandse toezichthouder is kritischer en stelt dat accountants meer hadden moeten letten op het totaalbeeld. Bovendien is het vaak gehoorde excuus van de complexiteit van de financiële wereld al een 'red flag' op zich (lezing Hans Hoogervorst, 16 juli 2009). De maatschappij mag zich dan ook afvragen of je van de accountant niet meer mag verwachten. Terecht worden er vragen gesteld rond de waarde van de audit, en hoe de maatschappelijke relevantie van het beroep verder versterkt kan worden. Het signaleren van risico's zou daar een belangrijk onderdeel van kunnen zijn. Zo is uit een onderzoek in 2008 van de Nederlandse beroepsorganisatie van accountants, het NIVRA, i.s.m. Eumedion gebleken dat de rapportage door beursgenoteerde ondernemingen op dit punt gebrekkig is. Ook de manier van auditrapportering lijkt voor verbetering vatbaar. Deze is erg gestandaardiseerd en een zogenaamde verklaring met voorbehoud zou ernstige gevolgen kunnen hebben voor een bank, zoals een zogenaamde 'bank run'. Rapporteringssystemen in andere domeinen, zoals gezondheid en veiligheid, kennen veel meer gradaties in rapportering waarbij opmerkingen meer courant zijn (Power, 2009). Wetenschappelijk onderzoek op dit terrein is dan ook zinvol.

Ook rond de structuur van multinationale kantoren kunnen zich terecht vragen worden gesteld. Ik weet niet of $u$ al eens heeft geprobeerd om de wereldwijde balans en winst- en verliesrekening van één van de Big Four accountantskantoren te raadplegen. Indien niet, bespaar $u$ dan de moeite want $u$ zal er lang naar moeten zoeken: deze bestaat namelijk niet! Herinnert u zich overigens de zaak Parmalat nog, de grote Italiaanse zuivelproducent, die een obligatielening van 150 miljoen euro niet kon terugbetalen hoewel er 4.5 miljard euro aan liquide middelen in de balans stond? De accountant was Grant Thornton en onmiddellijk 
na de publieke bekendmaking van de fraude, kwam de reactie van Grant Thornton uit de VS dat zij niets te maken hadden met Grant Thornton Italië. Er bestaat inderdaad een kloof tussen internationale beeldvorming en branding enerzijds, en nationale verdediging bij aansprakelijkheidsclaims anderzijds, wat de positie van multinationale kantoren onduidelijk maakt voor het maatschappelijk verkeer (De Accountant, a pril 2009). Op dit vlak zijn er recent een aantal interessante ontwikkelingen te noteren. Zo hebben Ernst \& Young (EMEIA) en KPMG al verschillende nationale organisaties gefuseerd, terwijl de regels, rechtspraak en toezicht in de betrokken landen nog verschillen. Op zich vormt dit een hele uitdaging. De klant en de maatschappij verwachten immers van een multinationaal kantoor: "1 beleid, 1 visie en 1 kwaliteit", aldus Philip Wallage van KPMG.

Net zoals voor ondernemingen en banken dient corporate governance of deugdelijk bestuur van accountantskantoren een prominentere rol te spelen in de toekomst. De nieuwe 8ste EU Richtlijn (juli 2006) heeft hiertoe een transparantieverslag voorgeschreven aan alle accountantskantoren. Deze beginnen nu stilaan gepubliceerd te worden. Belangrijk is dat accountantskantoren zich van deze verplichting niet kwijten door slechts zogenaamde 'boilerplate' gegevens te verstrekken, maar daarentegen dit verslag aanwenden om relevante informatie te verstrekken die een goed inzicht geven in haar corporate governance praktijken, waardoor gebruikers van auditdiensten meer geïnformeerde keuzes kunnen maken. De Europese Commissie beveelt de lidstaten ook aan meer openheid voor te schrijven aan accountantskantoren rond de uitkomsten van de inspectie die de toezichthouder bij het kantoor heeft uitgevoerd, welke in de jaarverslagen van de toezichthouder niet op individueel kantoorniveau bekend worden gemaakt (zie interview met Jürgen Tiedje, De Accountant, april 2009).

Een ander aandachtspunt voor accountantskantoren is permanente educatie. Zeker in een wereld van veranderende regelgeving, technologie en jawel... uitvinding van nieuwe complexe financiële producten, is dit van groot belang. Toch blijken hier soms problemen mee te zijn. Zo stuurde het NIVRA onlangs (juli 2009) 30 accountants naar de rechter omdat ze niet voldeden aan hun permanente educatie verplichtingen.

Een laatste aandachtspunt dat ik wil vermelden, is het belang van professioneel scepticisme. Accountantskantoren moeten ervoor waken 
dat hun accountants zich steeds professioneel sceptisch opstellen t.a.v. hun klanten en dit zowel in economisch goede als slechte tijden, en dit t.a.v. al hun klanten, dus ook t.a.v. diegene die op het eerste zicht heel betrouwbaar lijken.

\subsection{Rol van accountingonderzoek}

Bij een promotie tot doctor aan de UVA spreekt de promotor de promovendus aan het slot van de promotie toe met de woorden: "Waardeer de verkregen waardigheid als een eervolle onderscheiding en een gewichtig voorrecht en vergeet dan ook nooit de verplichtingen die zij u oplegt jegens de wetenschap en de samenleving". (Uit: "Accountancyhoogleraren, het is nu of nooit", Tom Nierop, 7 oktober 2008, accountant.nl).

Heeft de wetenschapper aan zijn verplichtingen verzuimd? De media is alvast erg kritisch voor de economische wetenschapper in brede zin, en er wordt gesteld dat de crisis in de economie ook een crisis is van de economische wetenschap (Haegens, 8 oktober 2008). Enkele voorbeelden: Waarom heeft de meerderheid van de economen dit niet zien aankomen?; Er wordt ook gesteld dat economen onvoldoende kritisch op het financiële systeem hebben gereflecteerd omdat ze er vaak onderdeel van uitmaken (bv. een groot deel van de Amerikaanse economen is rechtstreeks in dienst van financiële instellingen). Verder is er ook kritiek op de verwevenheid tussen de wetenschap en het bedrijfsleven, dat vaak optreedt als sponsor van onderzoek.

Hadden accountingonderzoekers deze crisis moeten zien aankomen? Wellicht niet, maar wat je wel zou mogen verwachten, is dat ze waarschuwen voor bepaalde fenomenen en praktijken die ze observeren, welke potentieel gevaarlijk zijn en mogelijk tot falen kunnen leiden. Het is belangrijk dat accountingonderzoekers voldoende kritisch zijn, maar tegelijkertijd ook constructieve analyses en oplossingen bieden bij vastgestelde problemen. Onafhankelijk onderzoek is hierbij van cruciaal belang. De publicatie van twee analoge papers (Frankel, Johnson \& Nelson, 2002; en Ashbaugh, LaFond \& Mayhew, 2003) in hetzelfde Amerikaanse top-tijdschrift met tegengestelde bevindingen rond de impact van adviesverlening ('non-audit services') op auditkwaliteit gemeten aan de hand van de kwaliteit van de gerapporteerde winstcijfers en in het bijzonder de mate van winststuring, heeft scherpe reacties uitgelokt (zie o.a. Francis, 2004). 
Hoewel er in de meeste universiteiten reeds lange tijd toegepast onderzoek wordt verricht, was er in elitaire universiteiten van oudsher enkel plaats voor fundamenteel onderzoek. Dit was gesteund op het Cartesiaanse perspectief waarbij het abstracte en het universele als waardevollerwordt gezien dan het toegepaste en contextuele (Diamond, 2005). Het gevolg is dat deze universiteiten dan ook bekritiseerd werden voor een gebrek aan interesse in het ontwikkelen van kennis om naar oplossingen te zoeken voor de talloze problemen waar de maatschappij tegen aan kijkt. Sommige universiteiten hebben hierop gereageerd door hun strategie aan te passen zoals bv. University of Southern California in 2004 (Diamond, 2005).

Een naar mijn oordeel ongunstige evolutie die zich binnen accountingonderzoek aftekent, is dat dit steeds enger dreigt te worden (zie o.a. Humphrey, 2005; Buijink, 2007; Hopwood, 2009). NoordAmerikaanse top-tijdschriften worden gedomineerd door de neoklassieke economische tradities, en publiceren voornamelijk kwantitatief, positivistisch kapitaalmarkt georiënteerd onderzoek (Humphrey, 2005). $\mathrm{Er}$ is weinig ruimte voor andere theorieën en methodologieën. In Europa is er wel meer een traditie om hier open voor te staan (bv. het werk dat gebeurd aan de London School of Economics, of het werk dat gepubliceerd wordt in het enige Europese top-tijdschrift Accounting, Organizations and Society met Anthony Hopwood uit Oxford University als editor, wat wel aandacht heeft voor gedrags-, organisatorische-, en sociale aspecten van accounting). Dit neemt niet weg dat jonge Europese accounting academici toch de weg verkiezen om te publiceren in één van de drie Noord-Amerikaanse top-tijdschriften omwille van zeer rationele economische redenen. Vooreerst is het incentive systeem daarop gericht. De Noord-Amerikaanse top-tijdschriften zijn de zogenaamde A-tijdschriften waaraan onderzoeksfinanciering en promotie is gekoppeld. Ten tweede verleent het je nationale maar vooral ook internationale credibiliteit als je erin slaagt om in die topbladen te publiceren. Ik geef toe dat ik hier ook schuldig aan ben, en ook toegegeven ben ik heel trots op mijn 2 recente publicaties (Simnett, Vanstraelen \& Chua, 2009; Carcello, Vanstraelen \& Willenborg, 2009) in één van deze tijdschriften, en dit is overigens wellicht ook de reden waarom ik hier vandaag voor $u$ sta. Toch ben ik van oordeel dat een verbreding van het accountingonderzoek wenselijk is. 
Accounting academici lijken meer en meer nadruk te leggen op methodologische nauwgezetheid, en veel minder op kennis die een maatschappelijke impact heeft, of inzicht geeft in de complexiteit van de praktijk. Het belang van methodologische nauwgezetheid staat niet ter discussie, maar soms gaat het erg ver en lijkt de remedie erger dan de kwaal (zie bv. discussie in Larcker \& Rusticus (2007) rond controle voor endogeniteit).

Verder vind ik dat accountingonderzoekers te weinig beleidsaanbevelingen geven, en te weining inspanning doen om de inzichten uit hun onderzoek te herverpakken in een begrijpbare taal voor een breed publiek zodat het nuttig is voor ondermeer beleidsmakers, het accountantsberoep en de toezichthouder (zie o.a. Francis, 2004). Dit zou in de toekomst veel beter kunnen. 


\section{Enkele aanbevelingen}

Welke inzichten leren we nu uit de crisis en hoe kunnen we uit de crisis geraken? Dit is een ambitieuze vraag, want een crisis zal je nooit kunnen vermijden, maar wat wel kan, is de kans en omvang verkleinen (zie o.a. Turner Review rapport, maart 2009). Hiertoe zal ik een aantal aanbevelingen formuleren.

\subsection{Regelgeving en toezicht}

Een eerste aanbeveling heeft betrekking op regelgeving en toezicht. Ik ben van oordeel dat de discussie zich niet moet concentreren op de ideologische as of er al dan niet meer regelgeving en toezicht moet zijn, maar wel rond de vraag wat is optimale regelgeving, en welke vorm van toezicht is efficiënt en effectief. Markten zijn immers geen vrijhavens. Markten moeten behoed worden voor ontsporingen, die van menselijke aard zijn. Mensen gedragen zich nu eenmaal niet altijd rationeel en psychologie speelt een belangrijke rol bij het nemen van beslissingen i.p.v. zuiver economische motieven. Dit was één van de belangrijke boodschappen van Keynes tijdens de crisis van de (19)30 er jaren, en wordt opnieuw duidelijk naar voren gebracht en verder uitgewerkt in het recente boek "Animal spirits: Hoe instincten in de mens de economie sturen" van Akerlof, nobelprijswinnaar economie in 2001, en Shiller. De crisis heeft geleerd dat we alerter moeten zijn voor ontsporingen van de markt, en de regels en het toezicht hebben hierbij gefaald. Vandaar dat ik ervoor pleit om meer na te denken over welke regels zijn zinvol, en welke niet. Met andere woorden, wat werkt wel, en wat werkt niet. Optimale regelgeving is immers geen kwestie van kwantiteit, maar van kwaliteit. Goede regels hebben is één zaak, toezicht op de naleving ervan is een andere, en beide zijn nodig. Net zoals voor regelgeving, dient er ook voor toezicht meer nagedacht te worden over de optimale vorm en omvang hiervan. Dat de huidige vorm en wijze van toezicht beter kan, althans door de Amerikaanse toezichthouder PCAOB, stond recent te lezen in een bijzonder kritisch artikel verschenen in Accounting Horizons, een tijdschrift van de American Accounting Association (Glover, Prawitt \& Taylor, 2009). Over de kwaliteit van toezicht buiten de VS is nog maar weinig bekend. Het is ook belangrijk dat een toezichthouder voldoende bevoegdheden krijgt om haar werk effectief en efficient uit te voeren. Zo wees Steven Maijoor, directeur bij de AFM en collega, op de te beperkte bevoegdheid van de AFM omdat er wettelijk geen overleg mogelijk is tussen toezicht financiële verslaggeving en toezicht accountants (Maijoor, 23 december 2008). Zowel op het gebied 
van regelgeving als op het gebied van toezicht kunnen onderzoekers een belangrijke bijdrage leveren, en dit brengt mij bij mijn tweede aanbeveling rond onderzoek.

\subsection{Onderzoek}

Ik pleit voor meer interactie tussen onderzoekers enerzijds, en regelgevers en toezichthouders anderzijds, voor het beantwoorden van de vraag rond optimale regelgeving en toezicht. Onderzoekers, en in het bijzonder in Noord-Amerika, hebben zich in het verleden vooral gericht op het onderzoeken van marktefficiëntie (zie bv. Ball, 1995). Vervolgens is er een stroom van literatuur op gang gekomen die de institutionele omgeving bestudeert om de werking van de markten beter te maken (zie bv. LaPorta, Lopez-de-Silanes, Shleifer \& Vishny, 1997). Zo is er ondermeer aangetoond dat de kwaliteit van financiële verslaggeving (bv. gemeten a.h.v. de mate van winststuring) gerelateerd is aan de kwaliteit van de institutionele omgeving, zoals bescherming van investeerders, en afdwingbaarheid van regels (zie o.a. Leuz, Nanda \& Wysocki, 2003; Francis \& Wang, 2008). Nu lijkt het tijd te worden om het onderzoek te richten op de vraag welk type van regelgeving en toezicht het best werkt. Dit lijkt me een relevantere onderzoeksvraag, dan zuiver ideologisch onderzoek naar of de markt al dan niet werkt, en of regelgeving en toezicht al dan niet werken. Hierbij aansluitend ben ik van oordeel dat onderzoekers een grotere inspanning moeten leveren bij het voorstellen van beleidsmaatregelen op basis van inzichten uit onderzoek, en dat zij meer moeten participeren in het politiek debat. Omgekeerd dienen regelgevers en toezichthouders ook lessen te trekken uit de resultaten die uit onderzoek naar voren komen. Verder zijn, zoals eerder vermeld, een verbreding van het onderzoek, meer aandacht voor maatschappelijk relevante thema's, en meer interdisciplinair onderzoek wenselijk.

Als auditonderzoekster pleit ik ook voor meer samenwerking met accountantskantoren. Toegang tot accountantskantoren is in de afgelopen jaren steeds lastiger geworden, zeker in de VS, waar men sinds de invoering van de Sarbanes-Oxley Act juridisch heel restrictief omgaat met het verschaffen van particuliere data aan onderzoekers. Dit is een ongunstige evolutie. Accountantskantoren vormen immers in belangrijke mate het onderzoeksobject. Bovendien denk ik dat accountantskantoren er ook baat bij kunnen hebben, en het de kwaliteit van assurance services ten goede kan komen. Voorwaarde is wel dat het onderzoek in vrijheid en onafhankelijkheid kan gebeuren. 


\subsection{Financiële verslaggeving}

Een laatste aanbeveling heeft betrekking op financiële verslaggeving. Zoals eerder uiteengezet, hebben accountingstandaarden economische effecten. Ik pleit er daarom voor dat aanpassingen aan accountingstandaarden met de grootste zorg gebeuren, en we geen boekhoudkundige kunstgrepen toelaten die het beeld van investeerders vertroebelen en tot inefficiënte economische besluitvorming leiden. Recent onderzoek (Francis, Huang, Khurana \& Pereira, 2009) heeft aangetoond dat transparante accountinginformatie zorgt voor een efficiëntere allocatie van middelen tussen sectoren en landen. Ondernemers en bankiers hebben hier ook een belangrijke rol te vervullen door hun verantwoordelijkheid op te nemen t.a.v. de kwaliteit van financiële verslaggeving, en dit brengt me terug bij het begin van deze oratie. Zoals de voormalige voorzitter van de AFM, Arthur Docters van Leeuwen, in een toespraak in 2004 terecht aangaf: "Financiële verslaggeving is één van de weinige vensters waardoor de doorsnee belegger een echte blik in een onderneming kan werpen. Het is dan ook de verantwoordelijkheid van het bestuur van ondernemingen om dat raam schoon te houden."

Rond de externe controle op financiële verslaggeving zijn ook een aantal lessen te trekken uit de crisis, maar deze laat ik over aan mijn collega Robert Knechel die hier in zijn rede zal op ingaan. 


\section{Dankwoord}

Mijnheer de Rector, gewaardeerde toehoorders,

Nu ik aan het einde ben gekomen van mijn betoog, zou ik graag enkele woorden van dank uitspreken. Een dag zoals vandaag komt immers niet zomaar aanwaaien, je moet er niet alleen hard voor werken, maar vooral ook de nodige ondersteuning krijgen van je familie, vrienden en collega's.

Allereerst dank ik de rector en het college van bestuur van de Universiteit Maastricht evenals het bestuur en de decaan van de School of Business and Economics voor het in mij gestelde vertrouwen door mijn benoeming tot hoogleraar.

Toen ik vele jaren geleden voor het eerst naar Maastricht kwam voor een PhD cursus auditing, had ik niet gedacht hier ooit hoogleraar te worden, laat staan een rede uit te spreken op ' $9 / 11$ ' welke toen nog niet in de geschiedenisboeken stond. Ik was op dat moment PhD-studente aan de Universiteit Antwerpen waar ik o.l.v. Ann Jorissen werkte aan mijn proefschrift, welke ik op de '4th of July', een heugelijkere dag in de Amerikaanse geschiedenis heb verdedigd. Ann Jorissen heeft een belangrijke rol gespeeld in het begin van mijn academische carrière en ik ben haar hier veel dank voor verschuldigd.

In de daaropvolgende fase heeft Steven Maijoor een belangrijke rol gespeeld. Hij heeft me overhaald om naar Maastricht te komen. Een heel bijzonder woord van dank is hierbij gepast. Aan Steven heb ik immers veel te danken: hij heeft me altijd gesteund tot vandaag toe, zijn enthousiasme werkte inspirerend en heeft me aangespoord om de lat telkens wat hoger te leggen, en hij was en blijft een voorbeeld voor mij.

Roger Meuwissen dank ik voor het in mij gestelde vetrouwen door mij te willen voordragen als hoogleraar. Verder dank ik de collega's van de faculteit, en in het bijzonder de collega's van het departement Accounting \& Information Management, onder aanvoering van Frank Moers, voor het creëren van een stimulerende omgeving.

Dank ook aan mijn vrienden en familie voor jullie aanwezigheid. Jullie hebben ver gereisd om hier vandaag te zijn. Ik waardeer dit zeer. 
Dank ook aan mijn grootmoeder: ik ben heel dankbaar dat zij deze feestelijke dag met mij kan delen, en mocht mijn grootvader er nog zijn, weet ik zeker dat hij erg trots zou zijn.

Mijn grootste dank gaat uit naar mijn ouders. Zij hebben er altijd voor gezorgd dat ik steeds de nodige aandacht en tijd kon besteden aan mijn studies en het onderzoek. Zonder hun niet aflatende zorg, liefde en steun gedurende alle voorbije jaren had ik hier vandaag nooit gestaan. Mijn moeder weet als geen ander wat het betekent om iemand in het gezin te hebben met belangstelling voor de wetenschap: mijn vader is immers ook hoogleraar. En inmiddels ondervindt ook Wim dat een dag als vandaag niet vanzelf komt, en wat belangstelling voor de wetenschap betekent. Veel dank daarom ook aan hem om hierin te willen meegaan.

Ik heb gezegd. 


\section{Referenties}

\section{Artikels in tijdschriften}

Allen, F. and E. Carletti. 2008. Mark-to-market accounting and liquidity pricing. Journal of Accounting \& Economics 45:358-378.

Ashbaugh, H., LaFond, R., and B. Mayhew. 2003. Do nonaudit services compromise auditor independence? Further evidence. The Accounting Review 78 (3), 611-639.

Ball, R. 1995. The theory of stock market efficiency: Accomplishments and limitations. Journal of Applied Corporate Finance 8 (Spring): 4-17.

Ball, R. 2009. Market and Political/Regulatory Perspectives on the Recent Accounting Scandals. Journal of Accounting Research 47(2): 277-323.

Buijink, W. 2007. Is accountancy onderzoek breed genoeg? Nee! Liber Amicorum Carl Reyns, Antwerpen: 157-166.

Caballero, R., Hoshi, T. and A. Kashyap. 2008. Zombie lending and depressed restructuring in Japan. The American Economic Review 98 (5): 1943-1977.

Carcello, J., Vanstraelen, A. and M. Willenborg. 2009. Rules Rather than Discretion in Audit Standards: Going-Concern Opinions in Belgium. The Accounting Review 84 (5): 1395-1428.

Diamond, M. 2005. Accounting education, research and practice: after Enron, where do we go? European Accounting Review 14 (2):353-362.

Doctors van Leeuwen, A.W.H. 2002. Toezicht op vertrouwen, vertrouwen op toezicht. Bestuurskunde 11 (3): 99-107.

Francis, J. 2004. What do we know about audit quality. The British Accounting Review 36 (4): 345-368.

Francis, J., S. Huang, I. Khurana, and R. Pereira. 2009. Does Corporate Transparency Contribute to Efficient Resource Allocation? Journal of Accounting Research: forthcoming.

Francis, J. R., and D. Wang. 2008. The Joint Effect of Investor Protection and Big 4 Audits on Earnings Quality around the World. Contemporary Accounting Research 25 (1):157-191.

Frankel, R., Johnson, M., and K. Nelson. 2002. The relation between auditors' fees for nonaudit services and earnings management. The Accounting Review (Supplement): 71-105.

Geiger, M., and K. Raghunandan. 2001. Bankruptcies, audit reports, and the Reform Act. Auditing: A Journal of Practice \& Theory 20 (March): 187-195. 
Glover, S., Prawitt, D. and M. Taylor. 2009. Audit Standard Setting and Inspection for U.S. Public Companies: A Critical Assessment and Recommendations for Fundamental Change. Accounting Horizons 23 (2): 221-237.

Hopwood, A. 2009. The economic crisis and accounting: Implications for the research community. Accounting, Organizations and Society 34 (7): 797-802.

Humphrey, C. 2005. In the aftermath of crisis: Reflections on the principles, values and significance of academic inquiry in accounting. Introduction. European Accounting Review 14 (2): 341-351. Kinney, W.R. 1999. Auditor Independence: Burdensome Constraint or Core Value? Accounting Horizons 13 (1): 69-75.

LaPorta, R., Lopez-de-Silanes, F., Shleifer, A. and R. Vishny. 1997. Legal determinants of external finance. Journal of Finance 52 (July): 1131-1150.

Larcker, D. and T. Rusticus. 2007. Endogeneity and Empirical Accounting Research. European Accounting Review 16 (1): 207-215.

Laux, C. and C. Leuz (2009). The crisis of fair value accounting: making sense of the recent debate. Accounting, Organizations and Society: forthcoming.

Leuz, C., Nanda, D. and P. Wysocki. 2003. Earnings management and investor protection: an international comparison. Journal of Financial Economics 69: 505-527.

Maijoor, S., and A. Vanstraelen. 2006. Earnings management within Europe: the effects of member state audit environment, audit firm quality and international capital markets. Accounting \& Business Research 36 (1):33-52.

Peek, J. and E. Rosengren. 2005. Unnatural selection: Perverse incentives and the misallocation of credit in Japan. The American Economic Review 95 (4): 1144-1166.

Plantin, G., Sapra, H. and H. Shin. 2008. Marking-to-market: panacea or pandora's box? Journal of Accounting Research 46: 435-46o.

Ramanna, K. 2008. The implications of unverifiable fair-value accounting: Evidence from the political economy of goodwill accounting. Journal of Accounting \& Economics 45: 253-281.

Sikka, P. 2009. Financial crisis and the silence of the auditors. Accounting, Organizations and Society 34 (6-7): 868-873.

Simnett, R., Vanstraelen, A. and W.F. Chua. 2009. Assurance on Sustainability Reports: An International Comparison. The Accounting Review 84 (3): 937-967. 
Skinner, D. 2008. Discussion of "The implications of unverifiable fairvalue accounting: Evidence from the political economy of goodwill accounting". Journal of Accounting \& Economics 45: 282-288.

Tiedje, J. 2009. Aan de reputatie van kantoren kunnen wij weinig doen. De Accountant april:20-22.

Van Amelo, L. 2009. Wereldwijde LAT-relatie. De Accountant april: 24-28.

Watts, R. and J. Zimmerman. 1978. Towards a positive theory of the determinants of accounting standards. The Accounting Review 53: 112-134.

Zeff, S. 2005a. The evolution of US GAAP: the political forces behind professional standards: Part I. The CPA Journal 75 (1): 18-27.

Zeff, S. 2005b. The evolution of US GAAP: the political forces behind professional standards: Part II. The CPA Journal 75 (2): 18-29.

\section{Artikels in kranten}

Bouwens, J. 26 november 2008. Accountant kan meer. Het Financieele Dagblad.

De Standaard. 23-24 mei 2009. Britse waakhond verzwijgt risico's.

De Tijd. 23 juni 2009. Boekhouders moeten plooien voor de politiek.

Haegens, K. 8 oktober 2008. Geen markt voor kritiek. De Groene Amsterdammer.

Haegens, K. 21 januari 2009. Wij zijn allen keynesianen. De Groene Amsterdammer.

Helderman, J. 8 november 2008. Accountant beseft belang 'zorgplicht'. Het Financieele Dagblad.

Maijoor, S. 23 december 2008. Bevoegdheid AFM is beperkt. NRC Handelsblad.

Sinn, H.W. 2 juli 2009. Einde bankcrisis nog lang niet in zicht. De Tijd.

Tweedie, D. Sir. 12 februari 2009. Markt ontdekte problemen sneller dan bankiers. De Tijd.

\section{Boeken}

Akerlof, G. en R. Shiller. 2009. Animal Spirits: Hoe instincten in de mens de economie sturen. Business Contact, Amsterdam.

Stiglitz, J. 2003. The Roaring Nineties: Seeds of Destruction. Penguin: London. 


\section{Lezingen en Toespraken}

Docters van Leeuwen, A.W.H. 12 oktober 2004. Wie houdt het raam schoon? Een toelichting op de rol van de toezichthouder bij financiële verslaggeving. www.afm.nl

Hoogervorst, H. 30 oktober 2008. Amsterdam. www.afm.nl Hoogervorst, H. 24 juni 2009. Milaan. www.afm.nl

Hoogervorst, H. 16 juli 2009. The auditor's role in the economic recession. Amsterdam. www.afm.nl

Suijs, J. 13 maart 2008. Transparante financiële verslaggeving: te mooi om waar te zijn? Inaugurele rede. Universiteit van Tilburg.

\section{Memoranda}

Policy and Regulatory Group. November 2008. Memorandum on accountancy and the banking crisis: the use of 'fair value' in financial reporting in times of uncertainty and illiquidity. www.parliament.uk

Power, M. January 2009. Memorandum on the banking crisis. www.parliament.uk

\section{Rapporten}

Report of the financial crisis advisory group, chaired by Harvey

Goldschmid and Hans Hoogervorst. 28 July 2009.

Report of the high-level group of financial supervision in the EU, chaired by Jacques de Larosière. 25 February 2009.

The Turner Review: A regulatory response to the global banking crisis.

Financial Services Authority. March 2009.

UK House of Commons Treasury Committee. The Run on the Rock. 26 January 2008.

UK House of Commons Treasury Committee. Banking Crisis: reforming corporate governance and pay in the City. 12 May 2009. 
